\title{
Influence of Debt Equity Ratio (DER) and Profit Per Share (EPS) against Stock Prices on Property and Real Estate Sub Sector Companies Listed on the Indonesia Stock Exchange 2015
}

\author{
Halimatu Sa'diyah, Didik Ardian, Helsinawati* \\ Economy and Business Faculty, Universitas Mercu Buana

\section{*Corresponding Author} \\ Helsinawati
}

\section{Article History}

Received: 10.08.2019

Accepted: 20.08.2019

Published: 25.09.2019

\begin{abstract}
This study aims to determine the effect of Debt to Equity Ratio (DER) and Earning Per Share (EPS) on Stock Price. The object of this study is the Company sub-sector Property and Real Estate listed in Indonesia Stock Exchange period 2015. The research design used is a comparative causal research. Sampling in this research is done by using purposive sampling technique. From the method obtained 35 companies that meet the criteria of a total of 47 companies during the observation period 2015. Data analysis used is statistical analysis in the form of multiple linear regression test. The result of t-statistic test shows that EPS has a positive and significant influence to stock price, whereas DER has a positive but not significant influence to stock price of property and real estate company listed on BEl in 2015.
\end{abstract}

Keywords: Debt to Equity Ratio (DER), Earning Per Share (EPS) and Price Stock.

\section{INTRODUCTION}

Debt to Equity Ratio (DER) is the ratio used to assess debt with equity. This ratio is sought by comparing all debt, including current debt with all equity (Kasmir, 2008). According to E. Yuliawati (2015) in his research on the Effect of DPS, DPR, PBV, DER, NPM and ROA on Stock Prices shows that PBV, NPM and ROA partially have a positive and significant effect on stock prices. Whereas the DPR and DER have no effect and are significant on stock prices.

According to Egam, et al. [1] that ROA, ROE is not effected by stock prices. Negative value on stock prices. While EPS has a positive effect on stock prices. Safitri [2] that Simultaneously EPS, PER, ROA, DER and MVA require the stock price. EPS, PER and MVA have a significant positive effect on stock prices. While ROA and DER are not significant to stock prices. Dewi and Suaryana [3] that effect of EPS, PBV on stock prices is significantly positive, while the effect of DER on stock prices is significantly negative. The third independent variable used in this study EPS, DER, and PBV together is of significant importance for stock prices. Pandansari [4]. that simultaneously ROA, DER, BV. Significant role on stock prices. Partially the fundamental factors of ROA, DER, and BVS have a positive influence on the stock prices of Manufacturing companies on the IDX in 2008-2010. Asmirantho and Yuliawati [5] that variable PBV, NPM and ROA partially, positively and significantly to stock prices. DPR variable has a negative and insignificant effect. Whereas DPS and DER do not apply and are significant to stock prices. Takarini and Hendrarini [6] that Financial Ratio and Its Effect on Company Stock Prices are variables of NPM, ROE, EPS and DER are not significant to stock prices. Whereas QR has a positive and significant impact on stock prices. Idawati and Wahyudi [7] that the results of this study indicate that EPS and ROA have a positive relationship with stock prices and simultaneously have a significant effect on stock prices. The better the company able to manage the intellectual capital have, the greater the value of Return on Assets (ROA) [8]. Current Ratio, Debt to Equity Ratio, Return on Equity and Total assets Turn over simultaneously is weak and not specific to Capital Gains [9].

Based on the previous description and remembering that financial ratios are one of the most important means for investors to assess the issuer's financial performance, as well as a consideration in making investment decisions which will ultimately affect the issuer's stock price movements.

Copyright @ 2019: This is an open-access article distributed under the terms of the Creative Commons Attribution license which permits unrestricted use, distribution, and reproduction in any medium for non commercial use (NonCommercial, or CC-BY-NC) provided the original author and source are credited. 
The purpose of this study which is based on the formulation of the problem is (a). To find out whether Debt To Equity Ratio (DER) has a significant influence on Stock Prices in the Property and Real Estate Sub-Sector Companies. (b). To find out whether Earning Per Share (EPS) has a significant influence on Stock Prices in the Property and Real Estate Sub Sector.

\section{MATERIALS ANd Method}

Financial management is one of the managerial functions found in companies that have an important role. Company management focuses on financial management carried out by companies or other parties, with the aim of getting maximum profit.

Basically financial management has two elements of words namely "Management" and "Finance". Financial management is one of the company's important operational functions. Financial management discusses financial management which basically can be done by individuals, companies, and the government.

According to Martono and Agus [10], financial management (Financial Management) is all company activities related to how to obtain funds, manage assets according to the overall goals of the company.

Whereas according to Husnan [11], financial management is concerned with the activities of planning, analyzing and controlling financial activities in an organization.

Based on the above understanding it can be concluded that financial management is all the activities of the company related to how to obtain, use, manage assets according to the overall goals of the company.

The definition of financial ratio according to Harahap [12] is a number obtained from the comparison of one financial statement post with another that has a relevant and significant relationship.

According to Kasmir [13] solvency ratio is a ratio used to measure which companies are financed by debt. Regarding the amount used by the company to finance its business activities compared to using its own capital. In other words, the large amount of debt borne by the company compared to its assets.

In the broad sense referred to as solvency ratios used to measure a company's ability, to determine how much the level of difficulty must be faced, the company must ensure that the requirements are better (dissolved). The types of solvency ratios used in this study are as follows.

According to Hanafi and Halim [14], shares are the latest claims of their order or rights. If the company adds to bankruptcy, then the existing cash is used to pay off, loans first, then later if needed, the cash is used to buy shares.

According Darmadji and Fakhrudin [15], shares are defined as an agreement or ownership of a person in a company or limited company. The tangible stock of paper that explains the owner of the paper is the owner of the company that issued the securities.

Based on the understanding of the shares above, it can be announced that the share is a piece of paper issued by the company as a sign of ownership of the company because it has deposited a certain amount of capital.

According to Sugiyono [16] that hypotheses are transient guesses or transient answers and still have to be verified. The hypothesis in this study is as follows:

\section{$H_{1}$ : Allegation Debt to Equity Ratio does a positive and significant influence to Stock Price}

$\mathrm{H}_{2}$ : Allegation Earning Per Share does a positive and significant influence to Stock Price

Data analysis is an activity after data from all respondents are collected. Activities in data analysis are grouping data based on variables and types of respondents, tabulating data based on variables from all respondents, collecting data for each variable collected, calculating to answer problems, and calculating to test hypotheses that have been proposed [16].

In this study the analytic method is a linear multiple regression analysis model with the help of SPSS software, to determine the significance level of each regression coefficient between the independent variables on the dependent variable, the statistical tests used are as follows:

\section{Descriptive Statistics Analysis}

According to Ghozali [17] descriptive statistics provide an overview or description of data seen from the average (average), maximum, minimum and standard deviation values. Whereas according to Widiyanto [18] descriptive statistics are only used toanalyze 
and classify research results that are not used in broad conclusions (generalizations). In this usage, the data used is sample data, so it is not for men who are organized in participants, only given sample images.

Analysis of the data used is quantitative methods. Quantitative descriptive method is recording data that consists of numbers that represent values and can be given an objective description of the problems in the analysis. This can be seen from the minimum, maximum, and average (average) value. The minimum value is the lowest value for each variable, while the highest value for each study variable. Value means the average value of each variable sent.

\section{Normality test}

The data requested on independent variables and non-independent variables has a normal distribution or not. Because the best data is normally distributed data or normal displacement. This statistical test was carried out through the Kolmogorov-Smirnov test.

\section{Statistical test criteria}

- If asymp. Significant (2-tailed) $>0.05$, the data meets the assumption of normality and accepted $\mathrm{H}_{0}$ but rejected $\mathrm{H}_{1}$

- If asymp. Significant $\left(2\right.$-tailed) $<0.05$, data cannot be distributed and rejected $\mathrm{H}_{0}$ but accepted $\mathrm{H}_{1}$.

\section{Multiple Linear Regression Analysis}

Basically, regression analysis is a study related to the dependent variable (bound) with one or more independent variables, with the aim of estimating and or predicting the average value of the dependent variable based on the independent independent variable values. In addition, regression analysis can also be used to show the direction between the independent variable and the dependent variable. Regression analysis in this study is multiple regression. With the regression equation model as follows:

\section{RESULTS AND Discussion}

\section{The result of Statistic Analysis as follows}

This test is supported to discuss whether the independent variables and non-independent variables have a normal distribution or not. The best data is data that has a normal distribution or nominal transition. The basis for making a decision is if Asymp. Sig (2-tailed) $>0.05$, then the data meets the normality assumption and vice versa.

Table-1: One-Sample Kolmogorov-Smirnov Test

\begin{tabular}{|l|l|l|l|l|}
\hline \multicolumn{2}{|c|}{} & LOG_Stock Price & LOG_EPS & LOG_DER \\
\hline $\mathrm{N}$ & 35 & 35 & 35 \\
\hline \multirow{3}{*}{ Normal Parametersa,b } & Mean & 2.7668 & 1.6591 & -.2091 \\
\cline { 2 - 5 } & Std. Deviation & .60492 & .87920 & .33266 \\
\hline \multirow{3}{*}{ Most Extreme Differences } & Absolute & .068 & .157 & .139 \\
\cline { 2 - 5 } & Positive & .068 & .098 & .091 \\
\cline { 2 - 5 } & Negative & -.067 & -.157 & -.139 \\
\hline Kolmogorov-Smirnov Z & .402 & .929 & .820 \\
\hline Asymp. Sig. (2-tailed) & .997 & .354 & .512 \\
\hline
\end{tabular}

Based on the table 1 show that stock variables has significance obtained is $0.997>0.05$, the conclusion is that the data are normally distributed. EPS variable has significant value obtained is $0.354>0.05$, then the conclusion is that the data are normally distributed. DER variable has significant value obtained is equal to $0.512>0.05$, then the conclusion is that the data are normally distributed.

This test can be used to show the direction of the relationship between the independent variable and the dependent variable. The test results of multiple linear regression analysis obtained by researchers are as follows

Table-2: Coefficients ${ }^{a}$

\begin{tabular}{|l|l|l|l|l|l|l|}
\hline \multicolumn{2}{|l|}{ Model } & \multicolumn{2}{l|}{$\begin{array}{l}\text { Unstandardized } \\
\text { Coefficients }\end{array}$} & $\begin{array}{l}\text { Standardized } \\
\text { Coefficients }\end{array}$ & \multirow{2}{*}{ Sig. } \\
\cline { 3 - 7 } \multicolumn{2}{l|}{} & B & Std. Error & Beta & \\
\hline \multirow{3}{*}{1} & (Constant) & 2.028 & .171 & & 11.863 & .000 \\
\cline { 2 - 7 } & LOG_EPS & .472 & .087 & .686 & 5.432 & .000 \\
\cline { 2 - 7 } & LOG_DER & .212 & .230 & .116 & .921 & .364 \\
\hline
\end{tabular}

The data above shows that the value of Sig. for DER is $0.364>0.05$, therefore the hypothesis rejected means that the DER variable has no significant effect on stock prices. Furthermore, for EPS variables the data above shows the Sig. amounting to $0,000<$ 0,05 , therefore the hypothesis is accepted, meaning that the EPS variable has a significant effect on the Stock Price. 
Table-3: Model Summary

\begin{tabular}{|l|l|l|l|l|}
\hline Model & R & R Square & Adjusted R Square & Std. Error of the Estimate \\
\hline 1 & $.700^{\mathrm{a}}$ & .490 & .458 & .44547 \\
\hline
\end{tabular}

The adjusting $\mathrm{R}^{2}$ determination coefficient is $45.8 \%$. This means that the independent variable is able to explain $45.8 \%$ changes in the dependent variable, namely shares. While the remaining $54.2 \%$ are explained by other variables outside the model.

The F statistic test shows whether all independent or independent variables included in the model have a joint effect on the dependent or bound variable. The F Test results obtained by researchers are as follows.

Table-4: ANOVAa

\begin{tabular}{|l|l|l|l|l|l|l|}
\hline \multicolumn{2}{|l|}{ Model } & Sum of Squares & df & Mean Square & F & Sig. \\
\hline \multirow{3}{*}{1} & Regression & 6.091 & 2 & 3.046 & 15.348 & $.000^{\mathrm{b}}$ \\
\cline { 2 - 7 } & Residual & 6.350 & 32 & .198 & & \\
\cline { 2 - 7 } & Total & 12.441 & 34 & & & \\
\hline
\end{tabular}

Based on the above data, obtained $F$ count value of 15,348 with a significant value of $0,000<0,05$, it can be concluded that the hypothesis is accepted, meaning that the DER and EPS variables have a significant effect together on stock prices.

This statistical test shows how far the influence of the independent variable on the individual explains the variation of the dependent variable. This test is used to determine whether the independent or real variables do not depend on the dependent variable. The following are the results of the $T$ test obtained by researchers as follows:

Table-5: t Test Coefficients ${ }^{a}$

\begin{tabular}{|c|c|c|c|c|c|c|}
\hline \multirow{2}{*}{\multicolumn{2}{|c|}{ Model }} & \multicolumn{2}{|c|}{ Unstandardized Coefficients } & Standardized Coefficients & \multirow[t]{2}{*}{$t$} & \multirow[t]{2}{*}{ Sig. } \\
\hline & & $\mathrm{B}$ & Std. Error & Beta & & \\
\hline \multirow[t]{3}{*}{1} & (Constant) & 2.028 & .171 & & 11.863 & .000 \\
\hline & LOG_EPS & .472 & .087 & .686 & 5.432 & .000 \\
\hline & LOG_DER & .212 & .230 & .116 & .921 & .364 \\
\hline
\end{tabular}

Based on the results above the EPS variable Estimated value is $0,000<0,05$, then $\mathrm{H}_{1}$ is accepted and $\mathrm{Ho}$ is rejected, so the EPS variable has a positive and significant effect on stock prices. While the DER variable is sig value $0.364>0.05$, then $\mathrm{H}_{1}$ is rejected and $\mathrm{Ho}$ is accepted. Increasing the DER variable has a positive effect on stock prices but not significantly on the stock price, mean increasing liability will increasing stock prices, but does not have a significant effect because significant values greater than 0.05 , this causes financing of projects financed by approved land and project property banks as working capital and cooperation in consumer credit contracts in the future.

\section{Discussion of Research Results}

Based on the results of data analysis of influence EPS and DER variables to stock prices as follows

The first hypothesis of influence of EPS variables to stock prices shows the Significant value of $0,000<0,05$ means hypothesis is accepted, meaning that the EPS variable does a positive and significant effect on the Stock Price, so $\mathrm{H}_{1}$ is accepted and $\mathrm{Ho}$ is rejected. This results is similar with several studies launched by Asmirantho and Yuliawati [5] and Safitri. A.L [2] that EPS have a significant effect on stock price.

Whileas the second hypothesis influence of DER variables to stock prices shows the Significant value of $0.364>0.05$, therefore the hypothesis is rejected means that the DER variable has positive but not significant effect on stock prices, so $\mathrm{H}_{0}$ is accepted and $\mathrm{H}_{1}$ is rejected. This results is similar with several studies launched by Asmirantho and Yuliawati [5] and Takarini and Hendrarini [6] is DER variable does not effect to stock price.

Effects of Earning Per Share on stock prices, based on test the hypothesis in this study to test the EPS between prices against stocks. Based on the results of statistical tests issued the test results show EPS variables It is estimated that the sig value is $0,000<0,05$, then $\mathrm{H}_{1}$ is accepted and $\mathrm{Ho}$ is rejected. EPS variable has a positive and significant effect on stock prices. This results is similar with several studies launched by Asmirantho and Yuliawati [5] and Safitri. A.L [2], with the conclusion that EPS have a significant effect on stock price.

\section{CONCLUSION}

Based on result on this aims that the Debt to Equity Ratio (DER) and Earning Per Share (EPS) to Stock Prices in the property and real estate sub-sector companies are listed on the Indonesia Stock Exchange (IDX) of 2015.The results of the analysis is the following conclusions can be obtained are effect of Earning Per Share (EPS) on Stock Price has a positive and significant effect on 
Stock Prices and effect of Debt to Equity Ratio (DER) on Stock Prices show that the Debt to Equity Ratio (DER) variable has a positive but not significant effect on the Stock Price.

\section{REFERENCES}

1. Egam, G. E., llat, V., \& Pangerapan, S. (2017). Pengaruh Return on Asset (ROA), Return on Equity (ROE), Net Profit Margin (NPM), dan Earning Per Share (EPS) terhadap Harga Saham Perusahaan yang Tergabung dalam Indeks LQ45 di Bursa Efek Indonesia Periode Tahun 2013-2015. Jurnal EMBA: Jurnal Riset Ekonomi, Manajemen, Bisnis dan Akuntansi, 5(1).

2. Safitri, A. L. (2013). Pengaruh Earning Per Share, Price Earnings Ratio, Return On Asset, Debt To Equity Ratio dan Market Value Added terhadap Harga Saham dalam kelompok Jakarta Islamic Index tahun 2008-2011 (Doctoral dissertation, Universitas Negeri Semarang).

3. Dewi, P. D. A., \& Suaryana, I. G. (2013). pengaruh EPS, DER, dan PBV terhadap harga saham. E-Jurnal Akuntansi, 215-229.

4. Pandansari, F. A. (2012). Analisis faktor fundamental terhadap harga saham. Accounting Analysis Journal, 1(1).

5. Asmirantho, E., \& Yuliawati, E. (2015). Pengaruh Dividen Per Share (DPS), Dividen Payout Ratio (DPR), Price To Book Value (PBV), Debt To Equity Ratio (DER), Net Profit Margin (NPM) dan Return On Asset (ROA) Terhadap Harga Saham Pada Perusahaan Manufaktur Sub Sektor Makanan dan Minuman Dalam Kemasan yang Terdaftar di BEl. JIAFE (Jurnal IImiah Akuntansi Fakultas Ekonomi), 1(2), 95-117.

6. Takarini. N \& Hendrarini, H. (2011). Rasio Keuangan Dan Pengaruhnya Terhadap Harga Saham Perusahaan Yang Terdaftar Di Jakarta Islamic Index. Journal of Business \& Banking (JBB), 1(2), 93-104.

7. Idawati, W., \& Wahyudi, A. (2015). Effect of earning per shares (EPS) and return on assets (ROA) against share price on coal mining company listed in Indonesia stock exchange. Journal of Resources Development and Management, 7, 79-91.

8. Kurniasih, A., \& Heliantono, H. (2016). Intellectual Capital Bank Bumn Terbuka Dan Pengaruhnya Terhadap Kinerja Perusahaan. MIX: Jurnal IImiah Manajemen, 6(2).

9. Wahyuni, I., \& Djamaluddin, S. Pengaruh Kinerja Keuangan Terhadap Capital Gain Pada Industri Properti Di Bursa Efek Indonesia (Periode Tahun 2008-2013). Jurnal IImiah Manajemen dan Bisnis Mercu Buana, 2(1).

10. Martono., \& Agus, H, D. (2010). Manajemen Keuangan. Yogyakarta: EKONISIA.

11. Husnan, S. (2014). Dasar-dasar Teori Portofolio dan Analisis Sekuritas. Yogyakarta: Unit Penerbitan dan Percetakan AMP YKPN.

12. Harahap, S.S. (2009). Analisis Kritis Atas Laporan Keuangan. Jakarta: PT. Raja Grafindo Persada.

13. Kasmir. (2013). Analisa Laporan Keuangan. Edisi 1.Cetakan Ke-6. Jakarta: Rajawali Pers.

14. Hanafi, Mamduh, M dan Abdul Halim. (2009). Analisa Laporan Keuangan. UPP STIM YKPN. Yogyakarta.

15. Darmadji, T., \& Fakhruddin, H. M. (2001). Pasar modal di Indonesia: Pendekatan tanya jawab. Salemba Empat.

16. Sugiyono. (2013). Metode Penelitian Kuantitatif Kualitatif dan R \& D. Bandung: Alfabeta

17. Ghozali, I. (2013). Aplikasi Analisis Multivariate Dengan Program IBM SPSS 21, Update PLS Regresi, Badan Penerbit Universitas Diponegoro, Semarang.

18. Widiyanto. M.A. (2013) Statistika Terapan, Konsep dan Aplikasi SPSS/Lisrel Dalam Penelitian Pendidikan, Psikologi dan IImu Sosial Lainnya, PT Elex Media Komputindo 